\title{
Mothers' milk: slavery, wet-nursing, and black and white women in the Antebellum South
}

Article

Published Version

West, E. and Knight, R. J. (2017) Mothers' milk: slavery, wetnursing, and black and white women in the Antebellum South. Journal of Southern History, 83 (1). pp. 37-68. ISSN 00224642 doi: https://doi.org/10.1353/soh.2017.0001 Available at https://centaur.reading.ac.uk/66788/

It is advisable to refer to the publisher's version if you intend to cite from the work. See Guidance on citing.

To link to this article DOI: http://dx.doi.org/10.1353/soh.2017.0001

Publisher: Southern Historical Association

All outputs in CentAUR are protected by Intellectual Property Rights law, including copyright law. Copyright and IPR is retained by the creators or other copyright holders. Terms and conditions for use of this material are defined in the End User Agreement.

www.reading.ac.uk/centaur 
Central Archive at the University of Reading

Reading's research outputs online 


\title{
Mothers' Milk: Slavery, Wet-Nursing, and Black and White Women in the Antebellum South
}

\author{
By Emily West with R. J. KNIGHT
}

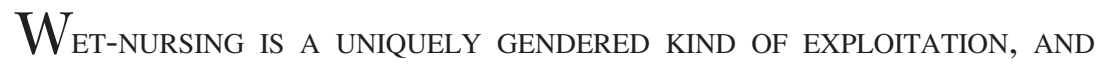
under slavery it represented the point at which the exploitation of enslaved women as workers and as reproducers literally intersected. Feeding another woman's child with one's own milk constituted a form of labor, but it was work that could only be undertaken by lactating women who had borne their own children. As a form of exploitation specific to slave mothers, enforced wet-nursing constituted a distinct aspect of enslaved women's commodification. The evocative image of an enslaved wet nurse, carefully holding a white child to her breast in order to provide sustenance through her own milk, therefore holds much resonance for historians interested in gender, slavery, and relationships between black and white women in the antebellum South. Wet-nursing bound women together across the racial divide, and white women also sometimes wet-nursed enslaved infants. Yet ultimately, white women used wet-nursing as a tool to manipulate enslaved women's motherhood for slaveholders' own ends.

This article evaluates patterns of wet-nursing in the antebellum South by locating the practice along a spectrum of gendered exploitation where enforced wet-nursing sits at one end, women's paid employment of "professional" wet nurses exists somewhere in the middle, and informal networks of support where women shared their breast milk lie at the other. Women in the antebellum South practiced forms of wet-nursing across this spectrum. Inextricably linked with ideologies of race, ethnicity, and class, historical patterns of exploitative wet-nursing have shaped contemporary distaste for the practice within the medical profession and elsewhere, even though informal networks of shared breast-feeding (for which little evidence survives) have probably been more common than has hitherto been recognized.

EMILY WEST is an associate professor of history at the University of Reading. R. J. KNIGHT is a Ph.D. student at the University of Reading. 
There have been many different forms of wet-nursing in the past, involving highly complex social relations. ${ }^{1}$ By exploring the practice within broader, long-run contexts of mothers' exploitation across time and space and under a variety of different regimes, one of which was antebellum U.S. slavery, historians can illuminate power structures that resonate with gendered, racial, and class exploitation, where a woman's race and status impacted her ability to make choices about infant feeding. Patterns of wet-nursing thus vary within different historical contexts; and while at times the practice might have involved acts of altruism by women who shared their milk, at other times, for example under antebellum slavery, wet-nursing took on a more exploitative angle. ${ }^{2}$ Wet-nursing fostered both physical closeness and racial distance between enslaved and white women, and opportunities for resistance on the part of enslaved wet nurses remained severely limited. Conversely, slaveholding women's relative power granted them choices about whether to use a wet nurse, and occasionally (and for a variety of reasons) white women wet-nursed enslaved infants. Enslaved women, too, sometimes shared their breast milk with each other in an example of more communal mothering processes. For the most part, though, wet-nursing represented a site of exploitation for enslaved women within the broader context of the antebellum slave regime. Slaveholding men and women manipulated enslaved women's mothering through their physical labor, their reproductive abilities, and the appropriation of their breast milk.

Wet-nursing is a complex and contingent process that has commonly involved women in unequal power relationships in a variety of different regimes whereby wealthier women use women from lower down the social scale as wet nurses. ${ }^{3}$ European female emigrants replicated these feeding patterns in colonial North America, using both

\footnotetext{
${ }^{1}$ Pam Carter, Feminism, Breasts and Breast-Feeding (Basingstoke, Eng., 1995), 27-28. The authors are grateful to the University of Reading, which funded some of this research as part of a University of Reading Undergraduate Research Opportunities Programme placement in the summer of 2012. Some of this article will feed into R. J. Knight's forthcoming Ph.D. dissertation, "'Mother, Home, and Mammy': Motherhood, Race, and Power in the Antebellum South" (University of Reading, ca. 2017). The authors are also grateful to David Stack, David Brown, and the anonymous reviewers at the Journal of Southern History for reading drafts of this article, and to all participants in the Arts and Humanities Research Council (AHRC)-funded "Mothering Slaves" Research Network for their insights into enslaved motherhood more broadly.

${ }^{2}$ Popular examples of altruistic wet-nursing can be found in the image of the Roman charity, where Pero breast-feeds her starving father, Cimon; and similarly, in the final scene of John Steinbeck's The Grapes of Wrath (New York, 1939), as Rose of Sharon breast-feeds a starving man.

${ }^{3}$ For long-term and transatlantic perspectives on wet-nursing, see, for example, Valerie Fildes, Wet Nursing: A History from Antiquity to the Present (New York, 1988); Valerie A. Fildes, Breasts, Bottles and Babies: A History of Infant Feeding (Edinburgh, 1986); Valerie Fildes, "The Culture and Biology of Breastfeeding: An Historical Review of Western Europe," in Patricia Stuart-Macadam
} 
enslaved and white wet nurses to feed their infants. Philip Vickers Fithian, a tutor in Robert Carter's Virginia household, wrote in his 1773 diary, "I find it is common here for people of Fortune to have their young Children suckled by the Negroes!"4 Utilizing enslaved women as wet nurses, in the colonial era and thereafter, undoubtedly made sound economic sense for white slaveholders. Paying for the services of a wet nurse was unnecessary when one could be procured for free from one's own chattel. ${ }^{5}$

Moreover, the association in whites' minds of black women's superior ability to suckle predates transatlantic slavery. European colonial travelers to West Africa frequently commented on black women's breasts as large and droopy and compared them to goats' udders. ${ }^{6}$

and Katherine A. Dettwyler, eds., Breastfeeding: Biocultural Perspectives (New York, 1995), 10126, esp. 101-12; Fiona Newall, "Wet Nursing and Child Care in Aldenham, Hertfordshire, 15951726: Some Evidence on the Circumstances and Effects of Seventeenth-Century Child Rearing Practices," in Valerie Fildes, ed., Women as Mothers in Pre-Industrial England: Essays in Memory of Dorothy McLaren (London, 1990), 122-38; Rebecca Lynn Winer, "Conscripting the Breast: Lactation, Slavery and Salvation in the Realms of Aragon and the Kingdom of Majorca, c. 12501300," Journal of Medieval History, 34 (June 2008), 164-84; Jane Khatib-Chahidi, "Milk Kinship in Shi' ite Islamic Iran," in Vanessa Maher, ed., The Anthropology of Breast-Feeding: Natural Law or Social Construct (Providence, R.I., 1992), 109-32; and Camillia Cowling, Conceiving Freedom: Women of Color, Gender, and the Abolition of Slavery in Havana and Rio de Janeiro (Chapel Hill, 2013), esp. 53.

${ }^{4}$ Hunter Dickinson Farish, ed., Journal and Letters of Philip Vickers Fithian, 1773-1774: A Plantation Tutor of the Old Dominion (new ed.; Williamsburg, Va., 1965), 39 (quotation); see also Philip Greven, The Protestant Temperament: Patterns of Child-Rearing, Religious Experience, and the Self in Early America (New York, 1977), 275. Julia Cherry Spruill gives several examples of white visitors commenting on the use of enslaved wet nurses in the southern colonies, concluding their use was "common." See Spruill, Women's Life and Work in the Southern Colonies (New York, 1938), 55-57 (quotation on 56). In contrast, Sally McMillen claims travelers to the South tended to overestimate the extent of enslaved wet-nursing because they tended to comment on practices and customs different from their own. See McMillen, "Mothers' Sacred Duty: Breast-Feeding Patterns among Middle- and Upper-Class Women in the Antebellum South," Journal of Southern History, 51 (August 1985), 333-56, esp. 335.

${ }^{5}$ However, as noted by Paula A. Treckel, colonial American women also faced pressures from Puritanical reformers and theologians who castigated mothers who employed wet nurses as "vain, Eve-like, and sinful in nature." Women's breasts, they argued, were primarily for feeding and should not be considered an erogenous zone. Some women might have been aware of breastfeeding's alleged contraceptive effects and thus prolonged their feeding in the hope of avoiding pregnancy. See Paula A. Treckel, "Breastfeeding and Maternal Sexuality in Colonial America," Journal of Interdisciplinary History, 20 (Summer 1989), 25-51 (quotation in note on 32). For further discussion of breast-feeding, wet-nursing, and contraception in the colonies, see Janet Farrell Brodie, Contraception and Abortion in Nineteenth-Century America (Ithaca, N.Y., 1994), 45-49. Jan Lewis and Kenneth A. Lockridge argue in "Sally Has Been Sick': Pregnancy and Family Limitation among Virginia Gentry Women, 1780-1830," Journal of Social History, 22 (Autumn 1988), 5-19, that women used breast-feeding to limit family size in late-eighteenth- and early-nineteenth-century Virginia. Janet Golden believes some American women gave their infant daughters to a wet nurse if they were desirous of a male heir and wished to become pregnant again quickly. Golden, A Social History of Wet Nursing in America: From Breast to Bottle (New York, 1996), 13-14.

${ }^{6}$ Stephanie M. H. Camp, Closer to Freedom: Enslaved Women and Everyday Resistance in the Plantation South (Chapel Hill, 2004), 63. 
According to Jennifer L. Morgan, early European travelers typically commented that West African women's breasts were long, enabling women to suckle their infants over their shoulders. Referring to these black African women's breasts as dugges - an archaic word that meant either a woman's breast or an animal's teat-also "connoted a brute animality." Morgan also shows how representations of West African women led into later erotic images of enslaved wet nurses, in order for slaveholders to rationalize both the sexual exploitation of enslaved women and the care they provided to white offspring. Ultimately, travelers' beliefs in black women's easy breast-feeding and childbirth laid the foundations for subsequent ideas about black African women's superior ability to perform hard manual labor. ${ }^{7}$ These two assumptions led to an entrenched system of dual exploitation of enslaved women's bodies as both reproducers and as workers. So while in the United States as a whole, wet-nursing declined over the course of the nineteenth century, in the South wet-nursing remained important, encompassing the multiple forms of exploitation inflicted on enslaved women's bodies. ${ }^{8}$

Southerners only occasionally fed infant slaves with bottles. For example, Works Progress Administration (WPA) respondent Susan Forrest believed that her mother was raised on a "suck bottle" after her grandmother's death. ${ }^{9}$ But the availability of lactating enslaved women reduced the demand for infant feeding bottles, which might

${ }^{7}$ Jennifer L. Morgan, Laboring Women: Reproduction and Gender in New World Slavery (Philadelphia, 2004), 27-36 (quotation on 33). See also Morgan, "'Some Could Suckle over Their Shoulder': Male Travelers, Female Bodies, and the Gendering of Racial Ideology, 1500-1770," William and Mary Quarterly, 3rd ser., 54 (January 1997), 167-92.

${ }^{8}$ Multiple factors explain wet-nursing's decline. Enlightenment ideas about "good," "modern" mothering encouraged "natural" methods of infant nutrition and care that included feeding one's own children. European writers from the eighteenth century onward increasingly celebrated notions of female domesticity and women's "duty" to breast-feed. See Fildes, "Culture and Biology of Breastfeeding," 102-3; and George D. Sussman, Selling Mothers' Milk: The Wet-Nursing Business in France, 1715-1914 (Urbana, 1982), 19-35. A new rhetoric of sentimental maternalism celebrated maternal love and breast-feeding, while discourses on motherhood increasingly celebrated "modern" maternity and bourgeois domesticity as noble and self-sacrificial. See Nora Doyle, “The Highest Pleasure of Which Woman's Nature Is Capable': Breast-Feeding and the Sentimental Maternal Ideal in America, 1750-1860," Journal of American History, 97 (March 2011), 958-73; and Henrice Altink, Representations of Slave Women in Discourses on Slavery and Abolition, 1780-1838 (New York, 2007), 38. A growing number of professionalized medical practitioners promoted breast-feeding one's own children instead of using wet nurses, advocating, as they do today, that "breast is best" unless under specific circumstances such as illness or an inability to produce milk. By the early twentieth century, mothers' use of bottled formula became widespread in the United States. See Golden, Social History of Wet Nursing, 50-51; and Fildes, Breasts, Bottles and Babies, 299-306.

${ }^{9}$ George P. Rawick, ed., The American Slave: A Composite Autobiography: Supplement, Series 2 (10 vols.; Westport, Conn., 1979), 4:1378; hereinafter cited as American Slave, suppl. ser. 2. 
risk a child's health anyway. ${ }^{10}$ Procuring a wet nurse from among the household's slaves, if such a woman was available, was a simpler option for slave-owning mothers. Bottles, though, were more willingly given to slave infants when their own mothers' milk was needed to feed white babies, whom whites inevitably prioritized over enslaved infants. WPA respondent T. W. Cotton said his grandmother fed him from a bottle in a rather complicated arrangement whereby Cotton's mother used her own milk to wet-nurse Walter, their mistress's son. "There was something wrong wid Miss Fannie," he recalled. Cotton's mother bore the brunt of slavery's exploitation by being forced to deny her own child her breast milk in order to feed a white infant instead. ${ }^{11}$

Tellingly, Giles Smith revealed how he was bottle-fed because there was no enslaved wet nurse to feed him after he, as an infant, was gifted away from his mother:

De Marster gave me to his daughter Mary, w'en I's jus' a few months old, an' had to be fed on de bottle. . . . She told me dat I's so young, dat she had a hahd time to feed me. 'Cause I's so young, milk am de only food I's could take, an' she had to use de bottle. Up to den, I's had nursed at de breast, an' I's fit de bottle. She says I's put up a good fight, an' come neah winnin' de battle, dat she am 'bout to tooks me back w'en I's finally gives in. I's guess hungah drove me to it. Dere was no cullud women on de Missy's place dat could nurse me, so dat's why deys nurse me on de bottle.

Smith's new owner's priority was to ensure this valuable enslaved infant survived into adulthood. Using a feeding bottle was a last resort in the absence of a lactating slave to nourish him. ${ }^{12}$

Wet-nursing under slavery has proved rather elusive to historians. In his recent work on the visual cultures of enslavement, Marcus Wood argues, "Black milk, slave mother's milk, was stolen in vast, unknown, incalculable quantities as generation after generation of white infants 'drank, and drank' from the nipples of the 'Mammy'

\footnotetext{
${ }^{10}$ Until the advent of modern techniques of sterilization, artificial feeding frequently caused ill-health and death among babies. Animal milk, from cows or goats, lacked the natural immunities of breast milk, and people were not fully aware of bacteria and the importance of sanitation. Keeping milk cool remained a difficult task in hot summers. McMillen, "Mothers' Sacred Duty," 348-49.

${ }^{11}$ Born in Slavery: Slave Narratives from the Federal Writers' Project, 1936-1938, Vol. 2: Arkansas Narratives, pt. 2, pp. 40-41; hereinafter cited as WPA Ex-Slave Narratives (LC), and available through the Library of Congress Digital Collections website, http://www.loc.gov/ collections.

${ }^{12}$ American Slave, suppl. ser. 2, vol. 9, p. 3602. A lack of available wet nurses may also explain why slaveholders tended not to separate enslaved infants from their mothers. Michael Tadman suggests only 2 percent of the domestic trade was made up of lone children aged 0-7 years. Tadman, Speculators and Slaves: Masters, Traders, and Slaves in the Old South (Madison, Wis., 1989), 151.
} 
and Mãe Preta [her Brazilian counterpart]." While Wood conflates the mammy stereotype with enslaved wet nurses, he regards this theft of enslaved women's milk as a point of trauma for enslaved women. ${ }^{13}$ Evidence from enslaved and formerly enslaved people supports this assertion.

Because the extent of wet-nursing under slavery is hard to quantify, historians have tended to define its use in the South as fairly unusual and to maintain that its significance is hard to evaluate. ${ }^{14}$ The practice has yet to receive systematic analysis from historians of U.S. slavery, and few studies specifically speak to enslaved women's concerns about their infant feeding practices. Most historians interested in wetnursing tend to offer speculative suggestions, citing Sally G. McMillen's detailed studies. ${ }^{15}$ Based on her extensive research into white women's evidence-mostly the letters, diaries, and journals of literate white women-supplemented with some use of WPA testimony, McMillen concludes that about one-fifth of white women relied on female domestic slaves for wet-nursing and that the practice of sharing breast milk across racial lines (including white women feeding slave babies) represented "one way some southern mothers rose above racial prejudice." 16

In contrast, this article stresses the exploitative elements of wetnursing and moves away from the notion that the practice exemplified racial closeness, intimacy, and affection between the black and white women who shared their breast milk. Instead, it suggests wet-nursing

\footnotetext{
${ }^{13}$ Marcus Wood, Black Milk: Imagining Slavery in the Visual Cultures of Brazil and America (Oxford, Eng., 2013), 2.

${ }^{14}$ Janet Golden simply notes, "Wealthy Southerners' access to slave wet nurses did not necessarily translate into their frequent use." Golden, Social History of Wet Nursing in America, 25.

${ }^{15}$ The most often-cited works on the practice among historians of the antebellum South remain Sally G. McMillen's Motherhood in the Old South: Pregnancy, Childbirth, and Infant Rearing (Baton Rouge, 1990); and McMillen, "Mothers' Sacred Duty." Ava Purkiss notes that while historians disagree on how customary enslaved wet-nursing was, available evidence suggests the practice was conventional. Ava Purkiss, "Wet Nursing," in Daina Ramey Berry and Deleso A. Alford, eds., Enslaved Women in America: An Encyclopedia (Santa Barbara, Calif., 2012), 334-35. This article concurs with Purkiss's view.

${ }^{16}$ McMillen, "Mothers' Sacred Duty," 336, 354 (quotation). See also McMillen, Motherhood in the Old South, 118, 130. Katy Simpson Smith agrees with McMillen that the majority of white southern women breast-fed their own infants and that most elite white women only used wet nurses when they had difficulties with or a "distaste" toward breast-feeding. Katy Simpson Smith, We Have Raised All of You: Motherhood in the South, 1750-1835 (Baton Rouge, 2013), 96, 187 (quotation in note). Likewise, Jane Turner Censer claims white women preferred to breast-feed their own children unless they were unable to do so due to "ill-health or an insufficient supply of milk." Censer, North Carolina Planters and Their Children, 1800-1860 (Baton Rouge, 1984), 35. Marie Jenkins Schwartz argues that white southerners provided infants, whether black or white, with wet nurses "when the mother could not breastfeed the child." Schwartz, Born in Bondage: Growing Up Enslaved in the Antebellum South (Cambridge, Mass., 2000), 67. This article suggests wet-nursing was more widespread than these authors assert.
} 
conveys ways that white women manipulated enslaved women's motherhood for their own purposes. This emphasis chimes with other recent works that stress the complicity of white southern women in enslaved wet nurses' abuse. Wilma A. Dunaway describes the practice as a form of "structural interference" in enslaved women's breastfeeding patterns. Slaveholders forced enslaved women to wean their own infants early (from around six months), so they could return to their labors; yet, ironically, wet nurses had to feed white children until they were about two years old. ${ }^{17}$ Referring to relationships between black and white women more broadly, Thavolia Glymph convincingly challenges assumptions that white and black women of the South shared experiences as dual victims of gender discrimination. White women instead used their power to inflict various horrendous acts of physical violence against the women they held in bondage. ${ }^{18}$ Furthermore, forcing black slave women to feed white infant children conveys one such form of abuse, taking away powerless women's milk purely for the benefit of others. ${ }^{19}$

${ }^{17}$ Wilma A. Dunaway, The African-American Family in Slavery and Emancipation (New York, 2003), 134-41 (quotation on 134). Similarly, Stephanie E. Jones-Rogers situates wet-nursing within wider processes of the marketization and commodification of enslaved women. She argues that the monetary value of enslaved mothers' breast milk increased these women's value in southern slave markets. Stephanie E. Jones-Rogers, "Black Milk: Maternal Bodies, Wet Nursing, and the Value of Black Women's Invisible Labor in the Antebellum Slave Market" (paper presented at the Berkshire Conference of Women Historians annual meeting, Amherst, Mass., June 2011), 1. We thank the author for sharing her paper. Daina Ramey Berry also argues that "skilled" laborers, including nurses (she does not specify wet nurses), commanded higher values than others. Berry, "Ter Show Yo' de Value of Slaves': The Pricing of Human Property," in William A. Link et al., eds., Creating Citizenship in the Nineteenth-Century South (Gainesville, Fla., 2013), 21-40, esp. 29-30.

${ }^{18}$ Thavolia Glymph, Out of the House of Bondage: The Transformation of the Plantation Household (New York, 2008), esp. 5, 139. Glymph also argues that most slaveholders in need of wet nurses looked no further than the quarters.

${ }^{19}$ From a comparative perspective, recent research on wet-nursing in other Atlantic slave regimes similarly highlights detrimental effects that the use of slave wet nurses had on enslaved women and their children. Camillia Cowling notes that the practice frequently denied enslaved women in Havana and Rio de Janeiro the chance to feed their own children. Cowling, Conceiving Freedom, 86-87. Similarly, Maria Helena P. T. Machado explains how Brazilian slaveholders denied enslaved babies sustenance by forcing wet nurses to prioritize white infants over their own. Machado, "Between Two Beneditos: Slave Wet-Nurses amid Slavery's Decline" (paper presented at the American Historical Association annual meeting, Washington, D.C., January 2014), 4, 11. We are grateful to the author for sharing her paper. The practice of using slave wet nurses was probably less common in those Caribbean islands with a tradition of absentee owners, but Sarah L. Franklin has a more positive interpretation of enslaved wet-nursing, concluding that it offered various material incentives for enslaved women through a thriving market for enslaved wet nurses in urban centers. Sarah L. Franklin, Women and Slavery in Nineteenth-Century Colonial Cuba (Rochester, N.Y., 2012), 125-46, esp. 146. An AHRC Research Network led by Diana Paton (University of Edinburgh), with Emily West (University of Reading) and Maria Helena P. T. Machado (University of São Paulo), is currently using comparative perspectives to explore motherhood, childlessness, and the care of children in Atlantic slave societies. 
However, a paucity of source materials renders wet-nursing hard to quantify. While McMillen concludes that only around one-fifth of white women relied on enslaved wet nurses, this portion can be read in more absolute terms. ${ }^{20}$ Historians disagree about the number of white slaveholders in the antebellum South. But calculations using an estimated figure of 350,000 slaveholders in 1850 as a benchmark (the majority of whom were men) and assuming these slaveholders had wives (of whom one-fifth used a wet nurse) suggest some 70,000 wet nurses across the antebellum South. ${ }^{21}$ So although the one-fifth of white women who used a wet nurse constituted a minority, in absolute terms a large number of enslaved women served as wet nurses yet remain absent from the historical record (WPA evidence certainly underestimates the extent of enslaved wet-nursing). ${ }^{22}$

Furthermore, in all types of primary evidence describing experiences of slavery, people, whether black or white, frequently failed to distinguish between a "nurse" who cares for children and a "wet nurse" who suckles children, because both terms were used interchangeably, as they had been since ancient times. ${ }^{23}$ The 1861 reminiscences of Louisa Picquet convey some of the confusion that can arise from this terminology: "When mother first went to Georgia she was a

${ }^{20}$ McMillen, "Mothers' Sacred Duty," 336; McMillen, Motherhood in the Old South, 118.

${ }^{21}$ For historiographical debates on the extent of slave ownership in the antebellum South, see Otto H. Olsen, "Historians and the Extent of Slave Ownership in the Southern United States," Civil War History, 50 (December 2004), 401-17. Sources permitting, the demographics of wet-nursing under slavery could be a fruitful area for future research.

${ }^{22}$ A search of all forty-one volumes of George P. Rawick, ed., The American Slave: A Composite Autobiography (19 vols.; Westport, Conn., 1972); Rawick, ed., The American Slave: A Composite Autobiography: Supplement, Series 1 (12 vols.; Westport, Conn., 1977), hereinafter cited as American Slave, suppl. ser. 1; and American Slave, suppl. ser. 2 (10 vols.) yields only fifty explicit references to wet-nursing by black or white women. Respondents might not have considered this topic worthy of comment, especially since many women wet-nursed only for a short period while lactating and performed additional labor elsewhere. Indeed, since interviewers did not ask the respondents questions about wet-nursing, most interviewees simply failed to mention it. However, many of the hundreds of references to "nursing" might have related to wetnursing. Furthermore, since most respondents were children or adolescents when slavery ended, most remained too young to have served as wet nurses themselves, and they may have been unaware of more senior women's exploitation in this realm. Just 16 percent of the informants were fifteen years or older when the Civil War began. See "Introduction," in John W. Blassingame, ed., Slave Testimony: Two Centuries of Letters, Speeches, Interviews, and Autobiographies (Baton Rouge, 1977), xvii-lxv, esp. 1. For more on the methodological issues arising from the use of WPA testimony, see Emily West, Chains of Love: Slave Couples in Antebellum South Carolina (Urbana, 2004), 5-8. For a recent defense of WPA evidence, see Edward E. Baptist, The Half Has Never Been Told: Slavery and the Making of American Capitalism (New York, 2014), 427-28n4. For the impact of the Great Depression on the testimony of the interviewees, see Stephanie J. Shaw, "Using the Ex-Slave WPA Narratives to Study the Impact of the Great Depression," Journal of Southern History, 69 (August 2003), 623-58.

${ }^{23}$ We are grateful to William F. MacLehose for sharing his views here. See his book " $A$ Tender Age”: Cultural Anxieties over the Child in the Twelfth and Thirteenth Centuries (New York, 2006). 
nurse, and suckled Madame Cook's child, with me. Afterward, she was a cook. I was a nurse. I always had plenty to do. Fast as one child would be walkin', then I would have another one to nurse." ${ }^{24}$ Louisa's mother was a "nurse" who "suckled," but Louisa seems to have been a "nurse" who simply cared for infants.

Dependent on lactating women to feed their infants, white women sometimes hired slave wet nurses from elsewhere if a woman was not available from their own chattel. ${ }^{25}$ In his study of Bourbon County, Kentucky, Keith C. Barton attributes a rise in the number of female domestics being hired by white families to new ideals of household management decreeing that white women should excel in their domestic sphere. In turn, this created new markets for enslaved women to "perform the drudgery that both women and men no longer considered a fit job for housewives," including laundry, cooking, and child care. Wet-nursing came under this broad category of child care, and Barton cites one man complaining to another about the difficulties of finding a "'healthy + suitable negro woman to suckle my little boys"” in springtime. ${ }^{26}$

Ultimately, wet-nursing remained, for many, a private experience, an unrecorded practice involving two women and an infant. ${ }^{27}$ However, historians can read deeply into the limited sources they do have available, and they can use their insight and training to speculate and extrapolate what it must have been like to be forced to feed another

\footnotetext{
${ }^{24}$ Louisa Picquet, the Octoroon: Or, Inside Views of Southern Domestic Life (New York, 1861), 7, available via Documenting the American South (University Library, University of North Carolina at Chapel Hill), http://docsouth.unc.edu/neh/picquet/picquet.html.

${ }^{25}$ Frequent advertisements for wet nurses, black or white, suggest that enslaved wet nurses were not always readily available. See Golden, Social History of Wet Nursing, 26-27; and Catherine Clinton, The Plantation Mistress: Woman's World in the Old South (New York, 1982), 155-56. Moreover, wet-nursing advertisements often ran for several days, indicating that white families found it hard to find wet nurses, even though they commonly advertised for any wet nurse, black or white, enslaved or free. McMillen, "Mothers' Sacred Duty," 351.

${ }^{26}$ Keith C. Barton, "'Good Cooks and Washers': Slave Hiring, Domestic Labor, and the Market in Bourbon County, Kentucky," Journal of American History, 84 (September 1997), 436-60 (first quotation on 457; second quotation on 440). Other historians of slave hiring have not explored wetnursing. For example, see Jonathan D. Martin, Divided Mastery: Slave Hiring in the American South (Cambridge, Mass., 2004). Deborah Gray White's groundbreaking research claims white slave owners tended to hire white nurses rather than use their own slaves, but she does not specify whether these were nurses or wet nurses. Deborah Gray White, Ar'n't I a Woman?: Female Slaves in the Plantation South (New York, 1985), 54.

${ }^{27}$ Janet Golden describes the practice as entailing "almost untraceable interactions." She also believes historians researching American wet-nursing face more challenges than do historians of European nations, where "scholars can turn to the archives of the church and of the state, as each institution was deeply involved in caring for infants and placing them with wet nurses." Golden, Social History of Wet Nursing, 7 (first quotation in note), 3 (second quotation in note).
} 
woman's child. ${ }^{28}$ Historians can employ humanity and compassion when exploring often invisible lives in the past in order to build up a more complete picture of slavery's trials for women, especially when researching the lives of mothers forced to feed their milk to others' babies. Wet-nursing hence sheds light on the contestations and struggle over what motherhood meant, its cultural specificities, and its practice for both black enslaved women and the white women who held them in bondage. ${ }^{29}$

For example, "southern" motherhood was distinctive, argues Katy Simpson Smith. It operated in a public sphere that allowed enslaved women a modicum of power through their public roles as providers, teachers, spiritual guides, protectors, and "aunts," even as they suffered under bondage. ${ }^{30}$ But white slaveholders manipulated and commodified enslaved women's motherhood by placing the needs of others, including the nutritional demands of infant children, above those of the mothers themselves. ${ }^{31}$ Ultimately, motherhood was and is, according to Evelyn Nakano Glenn, a "culturally variable relationship "in which one individual nurtures and cares for another." And in the United States, an idealized model of motherhood based on a white, middle-class notion that this responsibility rests squarely with biological mothers has been projected as universal. ${ }^{32}$

But, excluded from this dominant ideology of private, domestic motherhood, African American women have often practiced forms of shared mothering, for example by caring for kin regardless of whether one is a "biological" mother. Enslaved women shared their breast milk when white slaveholders forced them to labor away from their infants, or when they sold mothers away from their suckling babies, or when nursing slaves died. Wet-nursing under slavery acts as a prism that enlightens differing notions of motherhood and moves us beyond what Glenn describes as the binary ways motherhood has been perceived in much of Western culture: be this as a phenomenon applicable to females rather than males, bodies rather than minds, emotion rather

\footnotetext{
${ }^{28}$ Stephanie M. H. Camp argues persuasively that historians use their imagination in the absence of written testimony. Camp, Closer to Freedom, 95.

${ }^{29}$ See Evelyn Nakano Glenn, "Social Constructions of Mothering: A Thematic Overview," in Evelyn Nakano Glenn, Grace Chang, and Linda Rennie Forcey, eds., Mothering: Ideology, Experience, and Agency (New York, 1994), 1-32, esp. 18.

${ }^{30}$ Smith, We Have Raised All of You, 5-7, 179-80.

${ }^{31}$ More broadly, Patricia Hill Collins has critiqued a tendency among writers to "glorify" black motherhood, to celebrate and stereotype strong black women who nevertheless put everyone else's needs above their own. See Patricia Hill Collins, Black Feminist Thought: Knowledge, Consciousness, and the Politics of Empowerment (2nd ed.; New York, 2000), 174.

${ }^{32}$ Glenn, "Social Constructions of Mothering," 3.
} 
than reason, or a private rather than a public sphere. ${ }^{33}$ Ultimately, enslaved wet-nursing exposes how slave owners oppressed female slaves, including the oppression inflicted by white women who tried to manipulate enslaved women's motherhood for slaveholders' own ends by forcing female slaves to relinquish their own breast-feeding commitments as mothers in order to prioritize the families of their white owners. Wet-nursing provides the most literal and emblematic example of this manipulation of motherhood. ${ }^{34}$

White southerners commonly referred to senior female domestics (who may or may not have wet-nursed) as "mammy." A restrictive and controlling stereotype of white construction, mammy became revered during the Lost Cause era, when many white authors fondly recalled the prominent roles played by senior enslaved women in their plantation households as they simultaneously lamented the loss of both their individual slaves and the "peculiar institution" as a whole. ${ }^{35}$ Nostalgic memories of alleged intimate moments shared by white southerners and their enslaved mammies who wet-nursed them hence played a key role in this stereotype's evolution. For example, Mrs. John Wade recalled, "II had a black mammy, a very black one, and from her dark breast drew my infant sustenance, and smiled up into her face." Likewise, Robert Q. Mallard, a white man raised on a Georgia plantation, wrote, "As a babe, I drew a part at least of my nourishment from the generous breasts of a colored foster mother, and she and her infant son always held a peculiar place in my regards. A black nurse taught me, it is probable, my first steps and first words,

${ }^{33}$ Ibid., 5-7, 13.

${ }^{34}$ For more on the manipulating and revoking of enslaved women's motherhood, see R. J. Knight, "Precarious Bonds: Relationships between Mistresses and Slaves in the United States, 1800-1860" (M.A. thesis, University of Reading, 2014), 70; and Knight's forthcoming Ph.D. dissertation, "'Mother, Home, and Mammy."”

${ }^{35}$ For more on the mammy stereotype, see White, Ar'n't I a Woman?, 46-61; and Elizabeth Fox-Genovese, Within the Plantation Household: Black and White Women of the Old South (Chapel Hill, 1988), 291-92. Patricia Morton notes how two early historians of the South (Francis Butler Simkins and Clement Eaton) mention black mammies suckling white infants. See Morton, "'My Ol' Black Mammy' in American Historiography," in Caroline Matheny Dillman, ed., Southern Women (New York, 1988), 35-45, esp. 37-38. See also Jessie W. Parkhurst, "The Role of the Black Mammy in the Plantation Household," Journal of Negro History, 23 (July 1938), 349-69. For a more recent interpretation of mammy that shows how the term could be applied to a woman who served as a nurse or a wet nurse, see Kimberly Wallace-Sanders, Mammy: A Century of Race, Gender, and Southern Memory (Ann Arbor, Mich., 2008), 6-7. The evolution of mammy in the twentieth century, especially the way the term became conflated with cook, is explored in Rebecca Sharpless, Cooking in Other Women's Kitchens: Domestic Workers in the South, 1865-1960 (Chapel Hill, 2010), esp. xiii-xiv, 190. Succinct summaries of Lost Cause ideology are found in Nina Silber, The Romance of Reunion: Northerners and the South, 1865-1900 (Chapel Hill, 1993), 1-12; and Micki McElya, Clinging to Mammy: The Faithful Slave in Twentieth-Century America (Cambridge, Mass., 2007), 12. 
and was as proud of both performances as the happy mother herself." 36 A photograph of H. E. Hayward and his enslaved nurse, Louisa, typifies these white depictions of perceived racial intimacies (Figure 1).

Loyal and devoted to her "white family," mammy put all her energies into domestic work that sometimes included wet-nursing. She hence represented an idealized black womanhood for white slaveholders. ${ }^{37}$ Furthermore, the wider maternal connotations of the mammy stereotype meant that, in the eyes of whites, wet-nursing domestics illustrated the ultimate female slave. The stereotype therefore brutally exposes a contradictory racial ideology that simultaneously dismissed black women's ability to mother even as white women left their young children in enslaved women's arms for nurture and care, and sometimes even for suckling.

Forcing their female slaves to wet-nurse hence illustrates how slaveholders denigrated black women's mothering of their own children as innately inferior and paid scant regard to the very real difficulties faced by black mothers attempting to raise their children under a system of bondage. Unlike white women, female slaves spent most of their time forced to labor for another, so they could not devote the same amount of time and attention to mothering as white women. Enslaved women therefore partook in more shared and communal forms of mothering (including sometimes sharing their breast milk), and for female slaves the biological process of giving birth could be less significant than cooperating with each other to care for and nurture needy infants.

Enslaved women did not passively accept their dual exploitation as workers and reproducers, and many used their ability to bear children to resist the regime. ${ }^{38}$ WPA testimony suggests enslaved wet nurses could be well aware of the ironies of their treatment at the hands of

\footnotetext{
${ }^{36}$ Fox-Genovese, Within the Plantation Household, $431 n 35$ (first quotation); R. Q. Mallard, Plantation Life Before Emancipation (Richmond, Va., 1892), 9-10 (second quotation on 9), available via Documenting the American South, http://docsouth.unc.edu/fpn/mallard/mallard.html.

${ }^{37}$ See Collins, Black Feminist Thought, 69-96, esp. 71-72; White, Ar'n't I a Woman?, 58; and McElya, Clinging to Mammy, 82.

${ }^{38}$ Many historians have written about women's ability to resist their enslavement through their reproductive capacities. See, for example, Raymond A. and Alice H. Bauer, "Day to Day Resistance to Slavery," Journal of Negro History, 27 (October 1942), 388-419; Elizabeth FoxGenovese, "Strategies and Forms of Resistance: Focus on Slave Women in the United States," in Gary Y. Okihiro, ed., In Resistance: Studies in African, Caribbean, and Afro-American History (Amherst, Mass., 1986), 143-65, esp. 147-48; and Liese M. Perrin, "Resisting Reproduction: Reconsidering Slave Contraception in the Old South," Journal of American Studies, 35 (August 2001), 255-74. Diana Paton has recently critiqued the phrase "gynecological resistance" for focusing on enslaved women's bodies rather than their consciousness. We are grateful to the author for sharing her views and her unpublished paper, "Experiencing Pronatalism in the Anglophone Caribbean."
} 


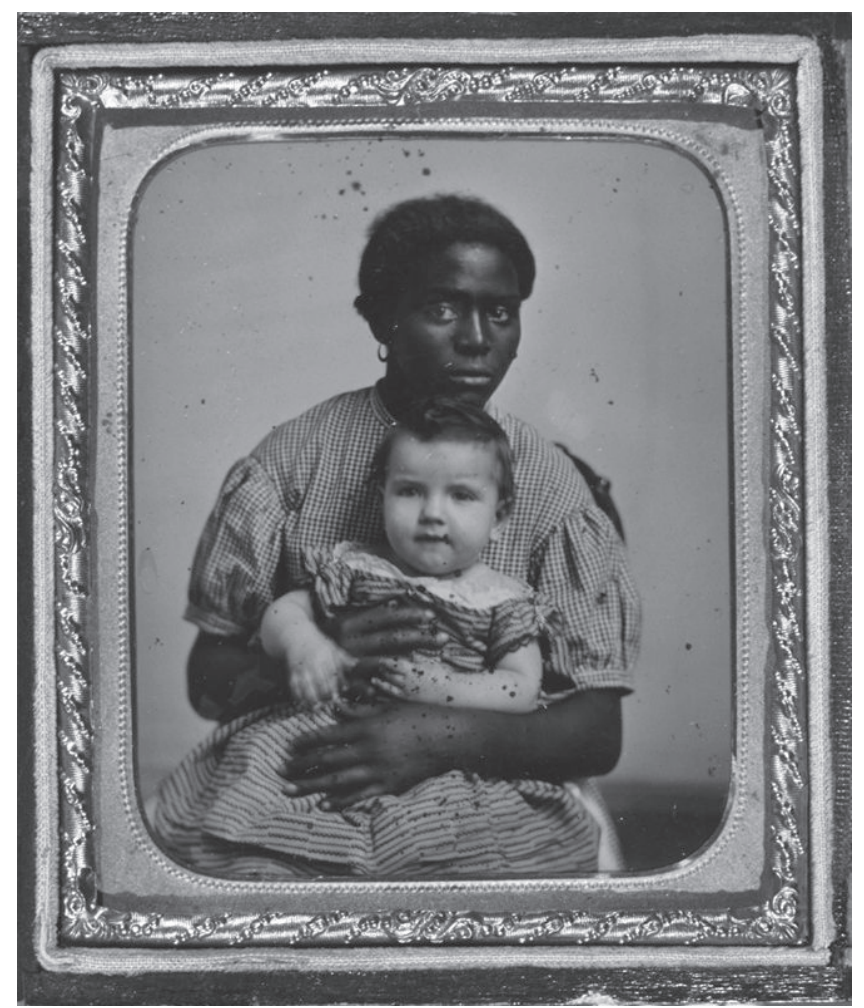

Figure 1. H. E. Hayward and slave nurse Louisa, ca. 1858. Daguerreotype, Ambrotype, and Tintype Collection, \#N21596 (Missouri History Museum, St. Louis, Mo.)

whites, who as infants gained their early sustenance from these women. Ellen Cragin recalled how her master's son threatened her mother with physical punishment. Ellen's mother cried, "'I'm goin' to kill you. These black titties sucked you, and then you come out here to beat me." 39 Enslaved women's bodies existed in a political area, as places of resistance, argues Stephanie M. H. Camp. Their bodies took on three dimensions: first, as a site of domination acted upon and exploited by slaveholders; second, as the subjective experience of that suffering and terror; and third, conversely, as a source of pleasure, pride, and self-expression. ${ }^{40}$ So while enslaved women might have taken pleasure and pride in their ability to breast-feed their own infants, their deployment as wet nurses by whites related to their first

${ }^{39}$ WPA Ex-Slave Narratives (LC), Arkansas Narratives, vol. 2, pt. 2, p. 42.

${ }^{40}$ See Stephanie M. H. Camp, "The Pleasures of Resistance: Enslaved Women and Body Politics in the Plantation South, 1830-1861," Journal of Southern History, 68 (August 2002), 533-72, esp. 538-45. 
and second bodies as sites of exploitation and commodification that deprived infants of their own mother's milk.

Wet-nursing also increased the amount of interaction between black and white women. Enslaved mothers with a ready supply of breast milk came into close contact with white women of the plantation house when the latter needed wet nurses for their babies, so slaveholders moved some lactating enslaved women out of the fields and into the "big house." But, even though serving as a wet nurse might bring some material benefits to enslaved women, enslaved women did not seek out a "promotion" away from the fields to work as wet nurses in their owners' houses. Nor did they seek to be hired out as wet nurses, separated from their loved ones and perhaps also their nursing infants. Enslaved women broadly rejected the notion that to labor in the big house was "better" than working in the field. ${ }^{41}$ Wet-nursing caused enslaved women emotional trauma as, unlike many white women, they lacked the ability to make choices about their infantfeeding patterns when they were forced to feed white infants instead of (or in addition to) their own offspring. Moreover, there were easier, more desirable ways of seeking better material conditions or attempting to obtain one's freedom. For enslaved women, wet-nursing ultimately remained a uniquely gendered form of exploitation of the highest order that compromised their motherhood.

The practice also provides a prism on the more intimate worlds of southern black and white women and allows historians to question the nature of the relationships between the two. White women's use of enslaved wet nurses provides evidence of both spatial closeness and racial distance between black and white women: for black women to breast-feed white children, sometimes at the expense of their own child (if their infants survived), their mistresses had to constantly watch over them, probably not allowing them out of their sight. That white women rarely complained about their slave wet nurses suggests that opportunities for enslaved women to resist were limited. ${ }^{42}$ They might try to sneak away and feed their own child first, thereby using up their milk supplies. Alternatively, women might have attempted to extract their breast milk manually in order to deprive white infants, but this course of action would also deprive their own child of nourishment. There was no means of escape for enslaved wet nurses,

\footnotetext{
${ }^{41}$ For more on the relative advantages of house and field labor for enslaved women, see West, Chains of Love, 84-85.

${ }^{42}$ For more on white women's lack of complaints about slave wet nurses, see McMillen, “Mothers' Sacred Duty," 352.
} 
trapped within the confines of plantation houses and farms, under the constantly watchful eye of white women. Furthermore, enslaved wet nurses whose own infants had died as a neonate no doubt experienced considerable emotional trauma when their owners then required them to feed another baby. ${ }^{43}$

WPA testimony supports the idea of wet-nursing as a uniquely gendered type of exploitation for commodified women. Condemned to frequent childbirth, like her white mistress, Mary Jane Jones's mother endured the additional burden of also feeding both her own infants and those of her mistress. Mary Jane explained:

I was ... the last litter of my mother's children. She was the mother of sixteen head of children and raised eleven of them [presumably the others died]. You see, my mother was a wedding gift to my marster at the time of his marriage; was given to him as a kind of nest egg to breed slaves for him, and jest as soon as he carried her home, he bought a slave husband fur her and children came to both families thick and fast. My mother would have a baby every time my mistress would have one, so that my mother was always the wet nurse for my mistress. ${ }^{44}$

Enslaved women such as Jones's mother, unfortunate enough to bear children at the same time as their mistresses, were an obvious first choice for whites seeking a wet nurse as they were already lactating. Jones's testimony strikes at the heart of the commodification of enslaved women's reproductive abilities when she suggests her mother was gifted to her master precisely because of her ability to reproduce, and hence also to produce milk. Enslaved in Alabama, Ruben Woods's mother had to suckle her master's son at the same time as Ruben himself. Amy Elizabeth Patterson's mother, Louisa Street, also had to wet-nurse her mistress's child of a similar age to her own. Likewise, Henry Clay Moorman's owners had a daughter, Sally, the same age as the respondent himself. As the interviewer reported, "Both children, being babies about the same age, the black mother served as a wet nurse for the white child, sometimes both the black child and the white child were upon the black mammies lap which frequently was the cause of battles between the two babies." ${ }^{25}$ The infant Moorman had no idea of his subservient status and was prepared to fight for his mother's milk.

\footnotetext{
${ }^{43}$ Thanks to an anonymous reader for this helpful suggestion about enslaved mothers whose infants died.

${ }^{44}$ American Slave, suppl. ser. 1, vol. 8, p. 1243.

${ }^{45}$ American Slave, suppl. ser. 2, vol. 10, pp. 4272, 4275; WPA Ex-Slave Narratives (LC), Indiana Narratives, vol. 5, pp. 150, 138 (quotation).
} 
Other respondents, especially those enslaved on large plantations of the Southwest, described almost institutional-style systems of infant feeding, where slaveholders took enslaved babies away from their mothers during the working day to be cared for in plantation nurseries and fed by wet nurses. This evidence illustrates how whites exploited enslaved women's bodies as workers and reproducers to the maximum by taking their milk for enslaved babies whose own mothers slaveholders forced to labor elsewhere. According to Jeptha Choice, "When babies were bo'n, old nigger grannies handles 'most all them cases, but until they was about three years old, the children wa'n't 'lowd 'round our regular living quarters, but were wet nursed by nigger women who did not work in the field and kept in separate quarters. In the evenin', the mammies were let to see them." Choice's master allowed his enslaved women only limited contact with their babies after their labors elsewhere were completed, and he did not permit them to suckle their own children during the day because he needed enslaved women as laborers to maximize his profits. On Clara Brim's Louisiana plantation, she recalled, "Dey uster had one ol' lady to cook for all de han's and one to ten' to de chilluns. And dey was a big bunch of dem chilluns, dey sho' was. Dey had a nuss woman what would give de li'l ones breas' nuss when dey mammies was out wukkin'." Life for wet-nursing slave women must have been both difficult and monotonous. They lived under a constant pressure to breastfeed, risking sore breasts, mastitis, and cracked and bleeding nipples while being isolated from the degree of camaraderie permitted to other slaves. Sarah Louise Augustus evoked the imagery of a chicken farm, and hence how masters applied wider agricultural techniques to slaveholding, when she described how her grandmother "wus called black mammy because she wet nursed so many white children. In slavery time she nursed all babies hatched on her marster's plantation." Augustus also conveyed something of the continuities of black women's oppression through Reconstruction, as she added that her grandmother maintained this role after the war. ${ }^{46}$

${ }^{46}$ American Slave, suppl. ser. 2, vol. 3, p. 709 (first quotation); American Slave, suppl. ser. 2, vol. 2, p. 429 (second quotation); WPA Ex-Slave Narratives (LC), North Carolina Narratives, vol. 11, pt. 1, p. 54 (third quotation). Other respondents spoke to the theme of institutional-style nurseries without explicit reference to wet-nursing. John Crawford, enslaved in Mississippi on a plantation of some nine hundred slaves, explained how his master "goes out to the nursing house every day and looks at the little niggers and pokes them in they bellies and fusses if they not fat and full. He hists them up in the air and says, 'This is a fine youngun.'" American Slave, suppl. ser. 2, vol. 4, p. 979. Similarly, Rosina Hoard said that people called her plantation nursery in Texas the "depot." It was "a big place . . . . Here all ob de chillun had to stay. Dere was a big yard where dey could play in." American Slave, suppl. ser. 2, vol. 5, pp. 1733-34 (quotations on 1733). 
Separating mothers from their own infants to wet-nurse white babies made it easier subsequently for white slaveholders to rationalize why they parted mothers and infants, because babies were no longer reliant on their own mothers' milk. Sometimes separations occurred simply by moving enslaved wet nurses into white houses, especially at night. In their Arkansas home, Josephine Howell's mother "suckled both Mrs. Will Thompson's children. . . . She lived in Mrs. Thompson's back yard but she slept in their house to help with the babies." So Howell's mother remained unable to feed her own children after dark, being forced to feed white infants instead. In South Carolina, Eugenia Woodberry hinted that she herself had wet-nursed white children at night: "I nu'se four head uv Miss Susan chillun a'ter she marry Massa Jim Stevenson. Sleep right dere wid dem chillun aw de time. Miss Susan ne'er didn't suckle none uv dem chillun." "Miss Susan" hence enjoyed unbroken sleep while her slave bore the brunt of arduous night feeds; Woodberry was simultaneously parted from her own family during the precious nighttime hours when most did not labor. ${ }^{47}$

Other WPA respondents also explained white women's use of wet nurses in terms of the convenience it provided them. Mattie Logan's mistress used a wet nurse to give her the freedom to visit her friends; she was not "tied to the place" and to her demanding baby's beck and call. Logan's mistress hence enjoyed a degree of freedom not usually permitted to new mothers. Her slaveholding status bought her the power to make choices about how to raise her infants and the ability to manipulate the motherhood of others to her own advantage. ${ }^{48}$ Betty Curlett believed white women avoided feeding their own infants for reasons of vanity, yet she also described some of the material benefits given to enslaved wet nurses, whom slaveholders permitted to feed their own children as well: "White women wouldn't nurse their own babies cause it would make their breast fall. They would bring a healthy woman . . . up to the house. . . . She would nurse her baby and the white baby, too. They would feed her everything she wanted. She didn't have to work cause the milk would be hot to give the babies. . . . Rich women didn't nurse their babies, never did, cause it would cause their breast to be flat." 49

White women's relative position of power and privilege compared with their enslaved women permitted them (unlike female

\footnotetext{
${ }^{47}$ WPA Ex-Slave Narratives (LC), Arkansas Narratives, vol. 2, pt. 3, p. 340 (first quotation); WPA Ex-Slave Narratives (LC), South Carolina Narratives, vol. 14, pt. 4, p. 218 (second quotation).

${ }^{48}$ WPA Ex-Slave Narratives (LC), Oklahoma Narratives, vol. 13, p. 187.

${ }^{49}$ WPA Ex-Slave Narratives (LC), Arkansas Narratives, vol. 2, pt. 2, pp. 76-77.
} 
slaves) to make their own decisions about whether to breast-feed their own children. They acted as "mother-managers" within their homes, possessing the power to delegate the most taxing and least desirable elements of motherhood to their slaves, including wetnursing, infant and child care, and caring for the elderly. ${ }^{50}$ They manipulated the motherhood of enslaved women for their own ends. For example, Ellen Vaden recalled how only a sense of modesty led her mistress to use an enslaved wet nurse: "Me and [owner] Dave Johnson's boy nursed together. When they had company, Miss Luiza was so modest she wouldn't let Tobe have 'titty'. He would come lead my mother behind the door and pull at her till she would take him and let him nurse." $" 51$

Even as some white women stressed, at least in principle, their opposition to using wet nurses, they could at least make choices about whether to use one. Suffering from a cold and earache, Anita Dwyer Withers wrote, "Dr. Dean came to see me this morning, he advises me to wean Johnnie and get a wet nurse if possible. I dislike it greatly, but I expect will have to do it." Withers recognized her position as a slaveholder granted her an opportunity to be spared the difficult and exhausting task of breast-feeding while unwell. Other white women simply found breast-feeding tiresome. Esther Cox, in a letter to her daughter Mary, explained how "your sister Rachel . . . complains of her Mary, being a tedious child to nurse." Rachel, luckily, had alternatives to the demands of a breast-feeding regime. ${ }^{52}$

\footnotetext{
${ }^{50}$ For more on "mother-managers," see Glenn, "Social Constructions of Mothering," 7 (quotation); and Barbara Katz Rothman, Recreating Motherhood: Ideology and Technology in a Patriarchal Society (New York, 1989), 198-202.

${ }^{51}$ WPA Ex-Slave Narratives (LC), Arkansas Narratives, vol. 2, pt. 7, p. 3. These respondents' testimony supports the claims of Paula Treckel that the social activities of planters' wives, as well as wider patriarchal power structures, militated against these white women nursing their own infants. Treckel suggests some white men pressured their wives into using wet nurses in the hope that they would regain sexual attention from them, although surviving evidence is scant. Treckel, "Breastfeeding and Maternal Sexuality in Colonial America," 33-34, 48. Early feminist writers such as Mary Wollstonecraft also claimed that fathers' desires for sexual relationships explained wet-nursing's survival more broadly. Vanessa Maher, "Breast-Feeding in Cross-Cultural Perspective: Paradoxes and Proposals," in Maher, ed., Anthropology of Breast-Feeding, 1-36, esp. 15,25 .

${ }^{52}$ Diary of Anita Dwyer Withers, February 25, 1864, p. 118 (first quotation) (Southern Historical Collection, Wilson Library, University of North Carolina at Chapel Hill), available via Documenting the American South, http://docsouth.unc.edu/imls/withers/withers.html; Esther Cox to Mary Cox Chesnut, March 25, 1800 (second quotation), Cox and Chesnut Family Papers (Digital Collections, South Caroliniana Library, University of South Carolina, Columbia, S.C.), http:// digital.tcl.sc.edu/cdm/compoundobject/collection/coxches/id/355/rec/44. Catherine Clinton also cites examples of white women complaining about the exhausting nature of breast-feeding, a practice they did not necessarily have to partake in. She also suggests that wet-nursing rose in the nineteenth-century South, as white upper-class women moved toward the use of white or enslaved wet nurses. Clinton, Plantation Mistress, 155-56.
} 
Always the outsider, Fanny Anne Kemble noted, perhaps a little haughtily, how southern racial hierarchies failed to prevent white women "from hanging their infants at the breasts of negresses." As usual, Kemble appeared well aware of the many ironies of slavery for women. ${ }^{53}$ More generally, white women's testimony about wet-nursing suggests a familiarity with the practice - that it was a fairly common occurrence, albeit something not often recorded. Hence visitors to the South were more likely to comment on wet-nursing practices in a manner similar to Kemble. For example, an Englishman named John Davis wrote, "It may be incredible to some that the children of the most distinguished families in Carolina are suckled by negro women. Each child has its Momma, whose gestures and accent it will necessarily copy, for children, we all know, are imitative beings. It is not unusual to hear an elegant lady say, Richard always grieves when Quasheeshaw is whipped, because she suckled him." "54 Davis was of the opinion that wet-nursing led to rather unseemly intimacy between blacks and whites. This type of discourse also played a role in antislavery sentiment more generally. A Union envelope of the Civil War era mocked the "Cotton States Aristocracy" for white southerners' intimate feeding at black breasts (Figure 2).

Wet-nursing also appeared in abolitionist writings because it provided a discourse of female exploitation easily adopted by antislavery activists seeking to appeal to contemporary tropes of feminine virtue and motherhood. 55 An 1863 account of "Dinah, an escaped Virginian Slave, Now in London," stressed the physical toll of wet-nursing on enslaved women's bodies and their ability to bear and raise living children: "In her husband's lifetime Di had fifteen children; many of them however were born dead from the effects of ill-usage; four times she had twins. She was wet-nurse to thirteen of her master's children, and these children were, in early years, under her care, and used to follow her about everywhere, with one or two of her own; she would carry them sometimes one under each arm and another on her back." Dinah must surely have struggled to cope emotionally with white children demanding her attention when she had lost so many of her own, while grappling with the physical exertion of simultaneously feeding

\footnotetext{
${ }^{53}$ Frances Ann Kemble, Journal of a Residence on a Georgian Plantation in 1838-1839 (New York, 1863), 23.

${ }^{54}$ John Davis, Travels of Four Years and a Half in the United States of America During 1798 , 1799, 1800, 1801, and 1802 (New York, 1909), 93-94.

55 The plight of enslaved mothers more broadly was a trope used by autobiographers to make a larger point about the inhumanity of slavery. Wallace-Sanders, Mammy, 52.
} 


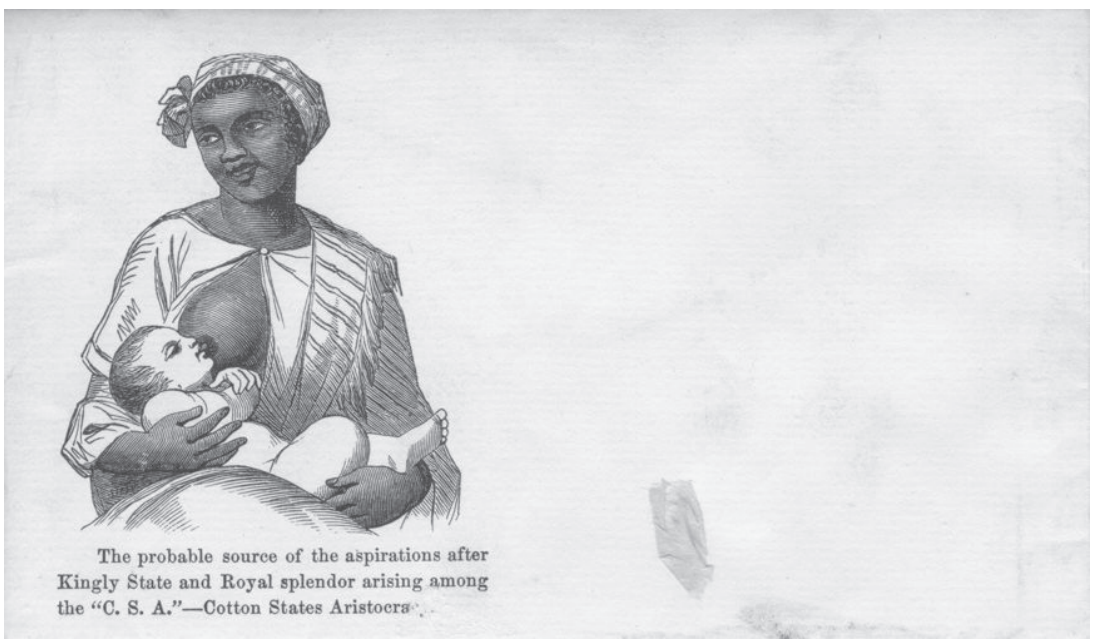

Figure 2. "Slave Nursing White Baby, Envelope 2," 1861-1865. John A. McCallister Collection: Civil War Envelopes (Library Company of Philadelphia, Philadelphia, Pa.)

her own many infants and thirteen of her owners'. Her life must have been extremely arduous as her owners used her motherhood as a commodity to be used for their own advantage. ${ }^{56}$ More hyperbolically, Hinton Rowan Helper's Impending Crisis of the South described a typical white southern man as "an abandoned wretch" who as an infant "sucked in the corrupt milk of slavery from the breasts of his father's sable concubines." $" 57$ Obviously not all white male infants fed on their female slaves' milk, just as not all white men forced enslaved wet nurses into entering sexual relationships with them. But antislavery discourses highlight some of the inherent ironies of a system that invoked ideologies of paternalism and racial closeness under a brutal and exploitative regime of bondage.

These ironies were not lost on Harriet Jacobs, who sought in her autobiography to appeal to "respectable" women of the northern states by promoting shared ideologies on black and white women's similar strengths and virtues as mothers. Jacobs's grandmother had been a

\footnotetext{
${ }^{56}$ John Hawkins Simpson, Horrors of the Virginian Slave Trade and of the Slave-Rearing Plantations: The True Story of Dinah, an Escaped Virginian Slave, Now in London, on Whose Body Are Eleven Scars Left by Tortures Which Were Inflicted by Her Master, Her Own Father; Together with Extracts from the Laws of Virginia, Showing That Against These Barbarities the Law Gives Not the Smallest Protection to the Slave, But the Reverse (London, 1863), 29.

${ }^{57}$ Hinton Rowan Helper, The Impending Crisis of the South: How to Meet It (New York, 1857), 169.
} 
wet nurse, and Jacobs initially depicted her grandmother's role in positive, even mammy-like tones: "She became an indispensable personage in the household, officiating in all capacities, from cook and wet nurse to seamstress. She was much praised for her cooking." But the reality of everyday life for Jacobs's grandmother, forced like many other enslaved women to labor as a wet nurse in addition to all her other tasks, must have been terribly onerous. Moreover, her white owners also forced her to wean her own infant (Jacobs's mother) at a very young age, in order to prioritize the health of her white charge, as Jacobs explained:

When I was six years old, my mother died . . . . My mother's mistress was the daughter of my grandmother's mistress. ... [T] hey were both nourished at my grandmother's breast. In fact, my mother had been weaned at three months old, that the babe of the mistress might obtain sufficient food. They played together as children; and, when they became women, my mother was a most faithful servant to her whiter foster sister. On her death-bed her mistress promised that her children should never suffer for anything; and during her lifetime she kept her word. They all spoke kindly of my dead mother, who had been a slave merely in name, but in nature was noble and womanly. ${ }^{58}$

Bearing in mind her intended audience of northern abolitionist women, it is unsurprising that Jacobs described wet-nursing in a manner that evoked racial closeness between black and white women. But other passages from her autobiography convey wet-nursing in a rather different light. At one point, Jacobs's (now free) grandmother attempted to use her past role as a wet nurse to "bargain" for better treatment of her family after hearing that James Norcom intended to punish Harriet Jacobs by sending her away to a plantation and selling her children. Jacobs's grandmother intervened:

She said she would go to the doctor [Norcom], and remind him how long and how faithfully she had served in the family, and how she had taken her own baby from her breast to nourish his wife. ... She went, and was treated as I expected. He coolly listened to what she said, but denied her request. He told her that what he did was for my good, that my feelings were entirely above my situation, and that on the plantation I would receive treatment that was suitable to my behavior. 59

Ultimately powerless, Jacob's grandmother failed in her vain efforts. Despite feeding white children from their own breasts, enslaved wet nurses did not always obtain "compensation and favors" for their efforts, because slaveholders were above all concerned with maximizing their exploitation of enslaved mothers'

\footnotetext{
${ }^{58}$ Harriet Jacobs, Incidents in the Life of a Slave Girl, Written by Herself, edited by L. Maria Child (Boston, 1861), 12 (first quotation), 14 (second quotation; emphasis added).

${ }^{59}$ Ibid., 129-30 (quotation on 130).
} 
bodies that generated milk, as both laborers and reproducers. ${ }^{60}$ And for some enslaved wet nurses, life was simply too hard to bear. "Another time," Jacobs related, "I saw a woman rush wildly by, pursued by two men. She was a slave, the wet nurse of her mistress's children. For some trifling offence her mistress ordered her to be stripped and whipped. To escape the degradation and the torture, she rushed to the river, jumped in, and ended her wrongs in death." 61 The unnamed mistress, who allowed her infants to be nursed from the breast of her slave, had no qualms about cruelly stripping and whipping this lactating woman who fed her children for her, even though the stress of receiving such a punishment had a devastating impact on her slave's presumably already fragile emotional self. For this ultimate victim of exploitation, suicide seemed like the only available option.

Some of the surviving testimony about enslaved wet-nursing conveys the sheer exploitative element of the practice: for example, when white women simply chose not to breast-feed or decided to alleviate the demands of breast-feeding by supplementing their own milk with that of one of their slaves. However, there also existed specific circumstances (other than personal choice) when white women used slave wet nurses. These included a belief among white women that they were unable to feed their children, mostly because they thought their milk supply was too low. ${ }^{62}$ In more extreme cases, physical or mental illness or the death of a mother resulted in the use of an enslaved wet nurse to ensure a child's survival, whether black or white. But whereas slaveholders fought for the survival of their own offspring due to the love they felt for them, they desired that enslaved children live because of their future financial value as commodities.

WPA respondent Jeff Calhoun explained how his mother suckled all fifteen of his master's children "'cause his wife was no good to give milk." ${ }^{33}$ Henry Lewis McGaffey's owners permitted him to feed at his mother's breast, so long as she made her other breast available to their white daughter, "Miss Amelia": "Sumthin' wus de matter wid my Mistiss an' she culdnt nurse her baby, so dey brung my mammy in de house an my mammy give one breast ter de white

\footnotetext{
${ }^{60}$ Katy Simpson Smith claims enslaved women used their wet-nursing experience to gain status within white households or as leverage for better conditions, "compensation and favors" for their families in the future. Smith, We Have Raised All of You, 187.

${ }^{61} \mathrm{Jacobs}$, Incidents in the Life of a Slave Girl, 184.

${ }^{62}$ See McMillen, "Mothers' Sacred Duty," 342-43, for more on white slaveholding women who had an inadequate milk supply.

${ }^{63}$ WPA Ex-Slave Narratives (LC), Texas Narratives, vol. 16, pt. 1, p. 188.
} 
baby an' de udder breast she give ter me."64 It is unknown whether the mistress's problem related to her mental or physical health, but the ability to have another woman suckle her child no doubt provided her with time and space in which to rest and recuperate.

White women sometimes shared their concerns about their milk supplies in their correspondence or diaries, and, unlike many enslaved women, they could resort to a wet nurse if they found feeding difficult. Ella Gertrude Clanton Thomas described in some detail how she made use of various slave wet nurses between 1861 and 1863, including America, Georgianna, Emmeline, and Nancy. In 1861, she wrote, "On Sunday we went down to the Rowell plantation for America. She has lost her baby which would have been three weeks old (had it lived) tonight. Pa has kindly permitted us to have her as a wet nurse for my baby. I do not give sufficient milk for him. I have tried cows milk. Then we had a goat. After we moved down here Georgianna nursed him and he commenced to fatten but her baby is nearly a year old and she did not have milk enough for both." Although it is not clear which infant Georgianna was able to prioritize through her breast-feeding, Thomas's belief that her slave did not have enough milk is revealing. She wanted her own son to receive maximum nourishment, so she sought another wet nurse instead of Georgianna, who had a limited milk supply. By 1863 Thomas had another infant, and she noted that "Pa has very kindly proposed that Emmeline, America's sister (who has a baby a few months old) can come and nurse the baby if Nancy's milk does not agree with her." While it is easy to sympathize with Thomas and her worries about providing enough milk, she was incredibly lucky to have so many women available to feed her children agreeable milk when animal milk and her own supply seemingly did not suffice. Yet the lack of empathy expressed in her journal is somewhat chilling. Thomas makes no reference to any feelings of compassion toward her father's slave, America, who had recently lost her own infant and was then forced to breast-feed another's. Thomas benefited because a female slave's child had died, and she failed to recognize America as a fellow mother. Thomas's priority was simply to ensure her own son had maximum nutrition, ideally from another woman's breast. ${ }^{65}$

Esther Cox and her daughter Mary Cox Chesnut corresponded at some length about Chesnut's difficulties in breast-feeding and her acquisition of a nurse. In 1801 Cox sent a salve to help with her

\footnotetext{
${ }^{64}$ American Slave, suppl. ser. 1, vol. 9, pp. 1394-95.

${ }^{65}$ Virginia Ingraham Burr, ed., The Secret Eye: The Journal of Ella Gertrude Clanton Thomas, 1848-1889 (Chapel Hill, 1990), 187 (first quotation), 218 (second quotation).
} 
daughter's hard and painful breasts when she was suffering from mastitis, an inflammation of breast tissue caused by breast-feeding. ${ }^{66}$ In April 1805, when Chesnut had another infant, Sally, mastitis seems to have caused a fever. Cox wrote, "I find by it that you are not likely to make a good Nurse - the Fever you have had will of Necessity lessen what Milk you had at first. . . . I rather think you will be like your Sister Sally in that respect and will be forced to relinquish the pleasure of giving Nourishment from your own breasts to the dear little Sally." She then suggested that Chesnut find "a good nurse," which, from the context of their conversation, must have meant a wet nurse. ${ }^{67}$ By July of that same year, Chesnut appears to have found herself a wet nurse, probably one of her own slaves, although the evidence is not clear on this point. Cox wrote to her daughter, "I have rec'd two [letters] of yours in the meantime, the last dated 4th of July-in which you say the pain in your breast still continues. I am sorry to hear it, lest it should weaken you too much—but you certainly did right to wean your Child from your own breast. I hope Sue will have milk enough to spare from her own child to nourish yours also."68 Again white women, in contrast to their slaves, were able to make choices about their infant-feeding practices and to utilize other women's motherhood to their own advantage and to make their own lives easier.

White slaveholders also made use of enslaved wet nurses when an infant's mother (whether a black slave or a white mistress) had died. Indeed, in the absence of well-developed techniques of artificial feeding, finding a wet nurse was often preferable to using feeding bottles, with all the health risks they entailed. ${ }^{69}$ In these cases compassion was also important because people wanted infants to survive. However, the pecuniary value of enslaved people played a role here, too, because slave owners had every reason to want their infant chattel to survive into adulthood as valuable human beings. So sometimes enslaved children fed at the breasts of black mothers who were not their own, while occasionally white women wet-nursed slave children. Interviewed by the WPA, Mary Reynolds told of sharing her mother's breast milk with her master's daughter, "Miss Sara Kilpatrick," following the death of his wife: "Dr. Kilpatrick's first wife and my maw

\footnotetext{
${ }^{66}$ Esther Cox to Mary Chesnut, March 7, 1801, Cox and Chesnut Family Papers, http://digital .tcl.sc.edu/cdm/compoundobject/collection/coxches/id/413/rec/18.

${ }^{67}$ Esther Cox to Mary Chesnut, April 21, 1805, Cox and Chesnut Family Papers, http://digital .tcl.sc.edu/cdm/compoundobject/collection/coxches/id/438/rec/60.

${ }^{68}$ Esther Cox to Mary Chesnut, July 23, 1805, Cox and Chesnut Family Papers, http://digital .tcl.sc.edu/cdm/compoundobject/collection/coxches/id/478/rec/64.

${ }^{69}$ McMillen, "Mothers' Sacred Duty," 348-49.
} 
come to their time right together. Miss Sara's maw died and they brought Little Miss Sara to suck with me."70 Other respondents also commented on enslaved women wet-nursing white infants after the death of their mistresses, including John F. Van Hook, whose granny was "loaned" to another white family who had an orphan child, and Fannie Tippin, whose mother fed her master's baby after his wife passed away. ${ }^{71}$

Enslaved in Georgia, William McWhorter did not shy away from clearly explaining the violent context behind enslaved wet-nursing following the death of a white mistress:

My Aunt Mary b'longed to Marse John Craddock and when his wife died and left a little baby_dat was little Miss Lucy_Aunt Mary was nussin' a new baby of her own, so Marse John made her let his baby suck too. If Aunt Mary was feedin' her own baby and Miss Lucy started cryin' Marse John would snatch her baby up by the legs and spank him, and tell Aunt Mary to go on and nuss his baby fust. Aunt Mary couldn't answer him a word, but my ma said she offen seed Aunt Mary cry 'til de tears met under her chin. ${ }^{72}$

Mary's tears of anguish poignantly convey the sheer desperation of enslaved wet nurses, trapped in situations where the manipulation of their motherhood meant their own children's needs came second to those of whites. And it is this enslaved perspective on wet-nursing that has been lacking from prior research into the subject. Wet-nursing caused enslaved women emotional trauma and compromised their maternal role.

Surviving testimony suggests overseers also sometimes forced slave women to suckle their children when nursing mothers had died. Enslaved to the Manigault family, Joaney had a child born dead. She then had to wet-nurse her white overseer's infant, whose mother had died of malaria. ${ }^{73}$ This must have been an incredibly traumatic experience for Joaney, as it was for other enslaved wet nurses, breast-feeding other children while simultaneously grieving for their own dead babies. Although letting other infants suckle at lactating breasts might have granted these women a measure of physical relief as they offloaded milk, they surely felt renewed anguish at their own babies' passing. Yet wet-nursing ultimately remained a bitterly complex practice: without it more babies would have died.

\footnotetext{
${ }^{70}$ American Slave, suppl. ser. 2, vol. 8, pp. 3284-85.

${ }^{71}$ WPA Ex-Slave Narratives (LC), Georgia Narratives, vol. 4, pt. 4, p. 74 (quotation); American Slave, suppl. ser. 2, vol. 9, p. 3879

${ }^{72}$ WPA Ex-Slave Narratives (LC), Georgia Narratives, vol. 4, pt. 3, pp. 96-97.

${ }^{73}$ William Dusinberre, Them Dark Days: Slavery in the American Rice Swamps (New York, 1996), 86.
} 
While female slaves forced to work as wet nurses found it hard to find ways of resisting this unique form of exploitation, enslaved women, like many others, no doubt felt a sense of feminine pride in their ability to breast-feed their young and in using this skill to assist their peers. However, evidence about these practices among enslaved women rarely survives; they constituted events that simply happened without anyone providing a written record. WPA respondent Charlie Davenport stressed the sense of camaraderie among enslaved women who shared breast-feeding responsibilities. Davenport said he was fed by a variety of enslaved women after his mother died while giving birth to him: "I was born one night an' de next mawin' my pore little Mammy died. Her name was Lucindy. . . . When I was a little mite dey turned me over to de 'granny nurse' on de plantation what tended to de picanninnies. She got a woman to nuss me who had a young baby so I didn't know no difference. Any woman what had a baby 'bout my age would wet nurse me so I growed up in de quarters en wuz ez well en happy ez any other chile." ${ }^{, 74}$ Davenport's testimony speaks to the shared, more communal nature of mothering practices among enslaved women who rallied together to support infant children. ${ }^{75}$

In the antebellum South, white women, as well as black, sometimes wet-nursed infants, and their reasons for doing so were complicated. Some WPA respondents spoke to the informal networks of support among black and white lactating women more generally. Gus Johnson, enslaved in Marengo County, Alabama, simply said, "My mudder was a wet nuss. Sometime' ol' mistus he'p nuss," implying that his mistress also suckled infants who were not her own. Mary Johnson recalled, "My ol' mistus she name Florence Walker. She was reglar tough, but she raise' me. I didn' hardly own my mama 'cause dey tek turns 'bout sucklin' all de chillen, w'ite and black." Likewise, Clayton Holbert remembered the existence of informal networks of support among white and black women, who shared feeding practices: "My mother used to be a cook, and when she was busy cooking, my mistress would nurse both me and her baby, who was four weeks older than me. If it happened the other way around, my mother would nurse both of us. They didn't think anything about it. When the old

\footnotetext{
${ }^{74}$ American Slave, suppl. ser. 1, vol. 7, p. 558. For more on white southern women's pride in breast-feeding, see McMillen, "Mothers' Sacred Duty," 342-43. However, the ability to make choices about feeding regimes strongly differentiated white women from their slaves.

${ }^{75}$ For more on "shared" mothering among African American women, see Glenn, "Social Constructions of Mothering," 5-7.
} 
people died, and they left small orphan children, the slaves would raise the children. My young master was raised like this." ${ }^{\text {76 }}$ This type of evidence suggests wider networks of camaraderie and support among black and white southern mothers with common interests. But, among enslaved and formerly enslaved people, these examples are less common than is testimony that highlights the exploitative elements of wet-nursing, where women's milk (whether black or white) constituted an economic commodity that enabled the survival of both financially valuable enslaved infants and cherished white offspring. ${ }^{77}$

WPA respondents often recalled slaveholders forcing female slaves to wean their babies early or else move to a highly regimented feeding regime so they could return to their productive labors elsewhere. ${ }^{78}$ In these cases, owners sought to maximize the enslaved women's exploitation as laborers rather than reproducers, leaving others to nourish their children (although some owners may also have hoped that once their female slaves stopped lactating they would become pregnant again). And so the milk of white mistresses could be extremely helpful to owners in enabling enslaved women to cease breast-feeding their own infants and to return to generating profits from their physical labor. For example, Rube Montgomery, enslaved in Choctaw County, Mississippi, believed he was weaned from his mother's breast at six months old: "I was born in October-my old Miss made Mamy wean me in March an' she (Old Miss) suckled me. I was jus' two weeks older 'n her child."79

Eva Martin, who had been enslaved in Louisiana, was even more explicit about the reasons why white women breast-fed enslaved infants, recalling, "Dey was seben li'l white chillen and seben li'l nigger chillen, and us all play togedder. De littles' ones all hab de same nurse. Ol' missus nurse 'em all from her own breas'. When my

\footnotetext{
${ }^{76}$ American Slave, suppl. ser. 2, vol. 6, p. 1989 (first quotation), 2023 (second quotation); WPA Ex-Slave Narratives (LC), Kansas Narratives, vol. 6, p. 3 (third quotation).

${ }^{77} \mathrm{~V}$. Lynn Kennedy notes how "in the intimate act of personally feeding and tending to the needs of an infant, there existed a recognition of the humanity of the child and at least the possibility of seeing the common interests of all mothers." But she also notes how "precious human beings" were also "precious economic investments." V. Lynn Kennedy, Born Southern: Childbirth, Motherhood, and Social Networks in the Old South (Baltimore, 2012), 102-3 (quotations in note on 103). Death rates among infant slaves could be extremely high. For a succinct summary, see William Dusinberre, "Power and Agency in Antebellum Slavery," American Nineteenth Century History, 12 (June 2011), 139-48, esp. 140. See also Richard Follett, "Heat, Sex, and Sugar: Pregnancy and Childbearing in the Slave Quarters," Journal of Family History, 28 (October 2003), 510-39, esp. 525-27.

${ }_{78}^{78}$ Dunaway, African-American Family in Slavery and Emancipation, 139.

${ }^{79}$ American Slave, suppl. ser. 1, vol. 9, p. 1561.
} 
mammy hab a kid, missus hab one, too. My mammy she go to wuk de nex' day atter she hab de kid and ol' missus she nurse 'em bofe so mammy ain't lose no time outer de fiel'." She then added pragmatically, "Dem slavery days." 80 Slaveholders used whatever techniques they could to maximize their exploitation of enslaved women's ability to generate money, even when that meant separating lactating mothers from their own infant children when alternatives were available. For example, Bessie Lawsom's white mistress wet-nursed her as a "sickly" infant. She explained how her mother was "needed . . . to work in the crop so bad." The mistress had a son, Jim, just slightly older than Bessie herself, "so I nursed one breast and Jim the other." ${ }^{11}$ The crop assumed priority.

Slaveholders often grappled with the dilemma of whether their exploitation of enslaved women as workers or as reproducers was most important. But, even when undertaken by white women, the process of wet-nursing shows how slaveholders prioritized female slaves' dual roles of worker and reproducer at different points in time. Once enslaved women had served their purpose as reproducers, they could be returned to field work or to their labors in slaveholders' houses, while another lactating woman, whether black or white, fed the infant children. White women no doubt suffered from patriarchal power when their husbands sometimes forced or otherwise cajoled them to breast-feed slave children whose own mothers were needed in the fields. However, white women's victimhood pales into insignificance when compared with that of enslaved women. Plus there was an obvious financial advantage for slaveholding families whose wives were able to breast-feed slave infants at the same time as their own. Owners forced enslaved mothers to return to their daily routine of work, especially at busy times of year such as the annual harvest, without the frequent disruptions caused by feeding a hungry child. Mistresses, of course, had easier lives than slaves and so would also have had more time and energy to nurse their valuable young slaves into positions of good health. As "co-masters" of the slaveholding regime, white women were aware of how they, as lactating mothers, could help foster their family's future wealth. ${ }^{82}$

So even when enslaved mothers died, the economic exploitation inherent in wet-nursing practices took precedence over more

\footnotetext{
${ }^{80}$ American Slave, suppl. ser. 2, vol. 7, p. 2583.

${ }^{81}$ WPA Ex-Slave Narratives (LC), Arkansas Narratives, vol. 2, pt. 4, p. 244.

${ }^{82}$ Glymph, Out of the House of Bondage, 123.
} 
individual instances of compassion among white mothers who fed slave babies. Rachel Perkins explained to her WPA interviewer, "They always told me mother died when I was three days old in the cradle. I don't fur a fact know much about my own people. Miss Agnes took me to raise me fur a house girl. She nursed me wid her Mary." 83 Mack Brantley's mistress also "suckled" him alongside her own daughter, "Miss Minnie," after the death of Brantley's mother when he was just six months old. ${ }^{84}$ Henry Gibbs did not explain why his mother did not raise him, simply saying, "My young Misses took me in her room when I was a sucklin babe and raised me. When someone wanted to buy me, she say 'no'-gold can't buy dat nigger, he's been too much trouble to me. He would a'died if I hadn't nursed him." Gibbs's mistress seemingly valued his presence because she was emotionally attached to him-he was priceless to her. However, it can be assumed that Gibbs also provided labor for his slaveholding family, labor that had a considerable financial value. White mistresses recognized that it was desirable from an economic perspective to have their infant slaves survive into adulthood, but it also took a degree of kindness (or cajoling from their husbands) to permit another woman's child to suckle at their own breasts, and these moments of intimacy occasionally led to ties of affection across racial lines.

That said, for white women suffering from an excess of breast milk, the ability to offload milk from leaking, painful, and swollen breasts to needy enslaved infants provided welcome relief. Mary Jones Mallard of Georgia apparently had to wet-nurse one of her slaves due to her " "abundance of nourishment." 86 And there could have been another reason why white women chose to wet-nurse enslaved infants. Although scientific explanations about breast-feeding's role in suppressing fertility were unclear at this time, some women might have believed that prolonged breast-feeding diminished their chances of getting pregnant. In antebellum times, when the physical and emotional costs of frequent childbearing were extremely high, white women may have chosen to prolong suckling in the hope of not falling pregnant. In contrast, their enslaved women, no longer lactating,

${ }^{83}$ WPA Ex-Slave Narratives (LC), Arkansas Narratives, vol. 2, pt. 5, p. 315.

${ }^{84}$ WPA Ex-Slave Narratives (LC), Arkansas Narratives, vol. 2, pt. 1, p. 241.

${ }^{85}$ American Slave, suppl. ser. 1, vol. 8, p. 822.

${ }^{86}$ McMillen, Motherhood in the Old South, 129-30 (quotation on 129). McMillen also writes that although some white women might have manually relieved themselves of excess milk, there was a lot to be gained, especially in a financial sense, from feeding infant slaves. McMillen, "Mothers' Sacred Duty," 354. 
had more chance of becoming pregnant and bearing yet more valuable slave children. ${ }^{87}$ Ultimately, despite the constraints of patriarchal power in the antebellum South, white women (unlike their female slaves) had a degree of control over the decision making around infant feeding.

In an 1848 interview in the Emancipator, Charity Bowery explained how her "mother suckled all [her master's] children." In consequence, her "mistress made it a point to give one of my mother's children to each of hers." Bowery's mother's reward for her years of labor was to witness each of her children being given away as presents to white people in a brutal reminder of slavery's processes of commodification. ${ }^{88}$ And in the southern states, patterns of wet-nursing that bolstered racial inequalities survived enslavement and continued into the early twentieth century. Black women in need of earning a living continued to work as wet nurses for white families, as WPA respondent Ellen Betts recalled: "Two year after de war, I git marry and git chillen of my own. Den I turn into a wet nuss. I wet nuss de white chillen and black chillen lak dey all de same color. Sometime I have a white un pullin' [on] de one side and a black one on t'other and dat de truth." 89

In the longer term, advances in artificial feeding techniques meant that by the early twentieth century bottle-feeding had replaced wet nurses in most countries, including the United States. However, professional wet-nursing (defined as women formally employed in the role) continued until the 1930s, when wet nurses were often based in hospitals but were sometimes still employed by individual families. ${ }^{90}$ In the modern world, practices whereby women share breast milk vary, influenced by tradition, custom, and cultural and religious patterns of belief. Some hospitals across the world continue to house

\footnotetext{
${ }^{87}$ Marie Jenkins Schwartz, Birthing a Slave: Motherhood and Medicine in the Antebellum South (Cambridge, Mass., 2006), 94. On the ways women used breast-feeding to limit fertility in West Africa, see Morgan, Laboring Women, 66-67. Richard Follett believes "the prevalence of wet nurses in [Louisiana's sugar parishes] indicates that some slaveholders attempted to optimize the potential reproductive capacity of their female property by manipulating lactational amenorrhea to establish large families within a relatively limited chronological span." Follett, "Heat, Sex, and Sugar," 527. In different contexts, some women may have sent their children to be wet-nursed to eliminate the ovulation-inhibiting factors of lactation. See Newall, "Wet Nursing and Child Care in Aldenham, Hertfordshire," 122; and Fildes, Breasts, Bottles and Babies, 107-9.

${ }^{88}$ Blassingame, ed., Slave Testimony, 261-67 (quotations on 262).

${ }^{89}$ American Slave, suppl. ser. 2, vol. 2, p. 269.

${ }^{90}$ Some wealthy European women continued to use wet nurses until World War I. Fildes, "Culture and Biology of Breastfeeding," 109; Fildes, Wet Nursing, 250.
} 
milk banks where women may donate their breast milk for babies whose mothers are unable to breast-feed. ${ }^{91}$

Modern research suggests wet-nursing presents some advantages, but also some dangers, to nurses and infant children. The benefits include optimal nutrition, digestibility, and immunological protection, but the risks include the transmission of infections caused by viruses and bacteria. Wet nurses feeding their own infants in addition to another can also struggle to produce enough milk, while mothers who give their babies to wet nurses to feed miss out on the benefits of breast-feeding, including the production of prolactin and oxytocin, hormones that relax both mother and child. In 2015 La Leche League International (LLLI) published new guidelines about milk sharing for infants "when their own mother's milk is unavailable." LLLI has advised against wet-nursing for a number of physiological and psychological reasons. ${ }^{92}$

Some recent advocates of milk-sharing have also attempted to rename wet-nursing "cross-feeding" in order to disassociate the practice from negative associations. ${ }^{93}$ Such negative connotations stem from patterns of historical wet-nursing, whether related to class or ethnicity. For example, in France, social class largely shaped wet-nursing patterns; within the different context of the southern United States, race shaped trends and traditions. ${ }^{94}$ The medical establishment hence remains wary of wet-nursing, ostensibly because of the health risks it brings, but maybe also because of the practice's contentious history in terms of women's relative power, race, and class and women's differing levels of ability to make choices about their infant feeding. Within the specific context of slavery, the examination of wet-nursing adds an extra dimension to our understanding of enslaved women's psychological and physical exploitation, their commodification by owners as

${ }^{91}$ This practice was first initiated in Austria in 1909, and the World Health Organization recommends breast milk from milk banks for premature babies when the mother's milk is not available. See "Iceland to Import Danish Breast Milk," The Guardian, October 22, 2014, http:// www.theguardian.com/world/2014/oct/22/iceland-to-import-breast-milk-denmark. As of September 2016, there were twenty-two human milk banks in the United States; see the Human Milk Banking Association of North America, https://www.hmbana.org/?mode=locations. Most recipients of this milk are premature babies in neonatal units.

92 La Leche League International, "Important Policy Update,” March 2015, http://www.1lli.org/ 1lleaderweb/lv/lvjulaug95p53.html. Because milk-sharing has often been a private act between women, it has not been well documented and remains largely absent from the historical record. For more on the benefits of breast-feeding, see Patricia Stuart-Macadam, "Biocultural Perspectives on Breastfeeding," in Stuart-Macadam and Dettwyler, eds., Breastfeeding, 1-37.

${ }^{93}$ Fildes, Wet Nursing, 270-71.

${ }^{94}$ On the role of social class in influencing infant feeding practices in France, see Penny Van Esterik, "The Politics of Breastfeeding: An Advocacy Perspective," in Stuart-Macadam and Dettwyler, eds., Breastfeeding, 145-65, esp. 148. 
both workers and reproducers, and the gendered exploitation of black women by white women, despite some informal networks of support in the realm of shared infant feeding. This history has relevance because ethnicity and social class still influence breast-feeding patterns. ${ }^{95}$ Every woman has the right to decide whether to breast-feed, but this important choice has been denied to some women in the past. In the realm of infant feeding, the ramifications of race and class still hold resonance today. This is wet-nursing's legacy.

${ }^{95}$ Rates of breast-feeding for black infants have been lower than those for Mexican American and non-Hispanic white infants. See Margaret M. McDowell, Chia-Yih Wang, and Jocelyn Kennedy-Stephenson, "Breastfeeding in the United States: Findings from the National Health and Nutrition Examination Surveys, 1999-2006," National Center for Health Statistics Data Brief, no. 5 (April 2008), http://www.cdc.gov/nchs/data/databriefs/db05.pdf. Urmeka T. Jefferson suggests the legacy of slavery has led to fewer black women breast-feeding their infants. Urmeka T. Jefferson, "Infant Feeding Attitudes and Breastfeeding Intentions of Black College Students," Western Journal of Nursing Research, 36 (November 2014), 1338-56, esp. 1340. See also Kimberly Seals Allers, "Breastfeeding: Some Slavery Crap?," Ebony, August 31, 2012, http://www.ebony.com/ wellness-empowerment/breastfeeding-some-slavery-crap\#axzz3KPLwXqlH; Susan M. LudingtonHoe, Patricia E. McDonald, and Rosemarie Satyshur, "Breastfeeding in African-American Women," Journal of National Black Nurses Association, 13 (July 2002), 56-64, esp. 57; and Bim Adewunmi, "Why Are Black Women Less Likely to Breastfeed?," The Guardian, July 23, 2012, http://www.theguardian.com/lifeandstyle/2012/jul/23/kimberly-seals-allers-breastfeeding -advocate. For a British perspective on the relationship between social class and infant feeding, see Eliane Glaser, "It's Class, Not Whether a Baby Is Breastfed, That Determines Life Chances," The Guardian, November 24, 2014, http://www.theguardian.com/commentisfree/2014/nov/24/class -baby-breastfed-life-chances-inequality. 